\section{University competition}

\section{Britain's newly diverse universities will be more vigorous} rivals for each other's funds in years to come.

Noт much is to be gleaned from the distribution of funds for the support of research at English universities announced last week (see page 4), except that the Matthew Principle ("to him who hath shall be given") continues to apply. One difficulty is that funds are now separately distributed to institutions of higher education in Scotland, Wales and Northern Ireland. Another is that the institutions previously called polytechnics are now mostly called universities. A third is that the English funding council has begun identifying separately its financial support for teaching and for research. Inevitably, the universities that have done well in their research allocations will be looking for even greater largesse to come. But may they be disappointed?

The new allocations derive from the exercise, occupying the past two years, in which the volume and quality of research at the traditional universities has been assessed by the few objective measures that exist. Mercifully, it has nevertheless been agreed that the full rigours of the Matthew Principle should not apply, and that even universities with little research should enjoy some research support. Otherwise, the research universities would be forever isolated from the competition less distinguished institutions can and will provide.

The competition may come more quickly than the research universities expect. There is a hint of that in the figures announced last week; some of the old polytechnics or 'new' universities will be more generously provided with research support than they were before. They will complain, with some justice, that, even now, their teachers will have to spend more time teaching than would be thought acceptable at the traditional universities, but at least they will now be more able than in the past to recruit people likely to win favours and funds. It would also be dangerously complacent of the research universities to suppose that the old polytechnics are no intellectual threat.

There is a second enemy of complacency in the traditional universities - the still uncertain outcome of the government's labouring on a new policy for harnessing research in Britain to 'wealth creation'. Although there are the strongest reasons why support for basic research should continue on something like its present scale, it seems unlikely that the mechanisms of research support will be left unchanged. Moreover, the greater diversity of institutions of higher education with which Britain is now endowed should be an asset, at least if they are able to compete for students, teachers and funds on equal terms.

The emergence of the new universities has inevitably occasioned some grumbling by the traditional universities. There has been particular alarm that the funds of $£ 175$ million or so now transferred from the universities' budget to the research councils to compensate grant-recipients for their overhead costs may be spread more widely. But fighting that battle must be unproductive, to say the best of it. Far better to fight for the funds required to get the best out of the enlarged university system that has sprung into being - and to preserve as much as possible of its diversity.

\section{France changes guard?}

\section{The Mitterrand government seems to be nearing its end, but the president himself may soldier on.}

THE general opinion in France that the present government will be defeated in the elections 17 days from now is probably correct. The call by senior figures in the ruling party for a new grouping of the centre-left is telling, as is the courtship of France's two green parties by all factions. Even if the president, M. François Mitterrand, decides to soldier on for part of the remainder of his second eight-year term, the chances are that he will then be even less in charge of events than during the short spell of cohabitation with the Chirac government of 1986. At best, it would be a sharp contrast with the heady election in 1981 when Mitterrand and his Socialist Party swept into power with an adventurous agenda of reform.

Much of that seems destined to endure. Mitterrand's socialism was never Marxism, although his first government was marked by a strong streak of syndicalism. His most dramatic innovation was the plan to increase public spending on research with the deliberate intention of making France more prosperous. For a year or so, budgets did actually increase by the 25 per cent a year promised. Although the accompanying programme of public ownership quickly caused a financial crisis and a change of course, the momentum was never entirely dissipated.

Not everything has turned out as intended, of course. The hope that France would become a giant in the computer business has been disappointed. And as elsewhere, too much of French industry remains over-closely tied to defence procurement. For better or worse, it is also true that there would not have been European civil aviation and aerospace industries without French pleading, even bullying. But there has also been a sustained wave of innovation in industries as different as chemicals and transport, notably on the railways. There has also been an improvement in the quality of higher education throughout France as well as a marked deepening of the education of graduate students. Those now searching for a recipe for wealth creation in Britain might do worse than take a leaf from Mitterrand's book.

Why, with this record, should Mitterrand's government be on the edge of extinction? Most of the explanation is political, but there are two respects in which the implications of a modernized France were never made clear to those affected. First, the logic that the creation of highly paid technical jobs makes farming less viable (or the cost of subsidies ruinous) seems not to have been explained to the rural communities of France. And France, as staunch a pillar of the European Communities as Germany, seems stubbornly to regard Europe as self-contained and potentially self-sufficient. Even if the opinion polls are right, not much of that is likely to change. 